\title{
Pre-Sowing Treatments Accelerate Germination Percent for Restoration of Fourteen Threatened Tree Species in Bangladesh
}

\author{
G.N.T. Hasnat*, M.A. Hossain and M.K. Hossain \\ Institute of Forestry and Environmental Sciences, University of Chittagong, Chittagong-4331, \\ Bangladesh
}

Date Received: 11-05-2018

Date Accepted: 23-12-2019

\begin{abstract}
Ecologically valuable native tree species are becoming threatened due to deforestation, forest fragmentation and preference of fast-growing exotics than the native ones in plantation. One of the main reasons for the preference of exotic species than the native ones is its higher rate of germination and rapid growth. The effect of different pre-sowing treatments was studied on fourteen threatened tree species of Bangladesh to find out the appropriate treatments for speed up germination rate and initial seedling growth. These species are ecologically valuable multipurpose indigenous trees of Bangladesh. Methanol extract of Castanopsis indica leaves could decrease the tumor Ehrlich Ascites Carcinoma volume and weight. Lophopetalum wightianum is a globally threatened tree species. Hard coated seeds of Canarium resiniferum, Castanopsis indica, Protium serratum, Quercus acuminata and Vitex peduncularis were treated with sand paper, nicking, normal water, hot water, $\mathrm{H}_{2} \mathrm{SO}_{4}$ and $\mathrm{HCl}$. Soft coated seeds of Brownlowia elata, Dichopsis polyantha, Firmiana colorata, Lophopetalum wightianum, Pterospermum acerifolium, Pterospermum semisagittatum, Pterygota alata, Schleichera oleosa and Sterculia villosa were sown in polybags, propagator house and nursery bed in normal, flat and $45^{\circ}$ angle positions. Among all hard-coated seeds, Castanopsis indica showed significantly higher germination percentage (67\%) after seeds treated with sandpaper in comparison to control (25\%). Soft-coated seeds of Lophopetalum wightianum showed significantly higher germination percentage (90\%) among all studied species when sown in propagator house, whereas in natural condition it provides only $26 \%$ germination rate. This paper will help to restore ecologically valuable threatened species.
\end{abstract}

Keywords: Pre-sowing treatment, globally and nationally threatened tree species, germination rate, hard or soft-coated seed, Bangladesh

\section{Introduction}

Bangladesh had a rich floral diversity containing about 5,700 species of angiosperms (Khan, 1977; Hossain, 2001). However, the floral diversity has been disrupted (Haque et al., 1997; Uddin and Misbahuzzaman, 2007; Hossain et al., 2012) and the natural forests have been degraded along with its native tree species (Hossain, 2001; Hossain et al., 2012). Native tree species are becoming threatened due to forest disturbance and hazardous invasion of fast-growing exotics (Islam, 2003; Afrin, 2010; Mangla et al., 2011). A total of 486 plant species in Bangladesh are considered as threatened of which 449 are angiosperms (Irfanullah, 2011). Among these, some valuable timber species are also included, which are ecologically and economically important (Khan et al. 2001; Hossain et al. 2004). One of the ecologically valuable timber species is Castanopsis indica (Roxb.), commonly known as Shil Batna, which has medicinal value too. Methanol extract of Castanopsis indica (MECI) leaves has a significant effect on Ehrlich Ascites Carcinoma (EAC) cell. A dose of dependent manner can decrease the tumor volume and tumor weight, and elevate the life span of EAC tumor bearer (Dolai et al., 2012).

*Correspondence: gnthasnat@yahoo.com ISSN 2235-9370 Print/ISSN 2235-9362 Online (C) University of Sri Jayewardenepura 
Another important native tree of Bangladesh is Lophopetalum wightianum (Arn.), locally known as Raktan, a globally threatened tree species (IUCN, 1998). Natural regeneration of exotic species through seed dispersal is too high than native tree species (Flores-Moreno, 2013). The germination rate of major plantation exotic species is also greater than native species (Klink, 1996; Wainwright and Cleland, 2013). In natural forests as well as in plantation, natural regeneration of some native species is very low (Hossain, 2003; Uddin et al., 2013) because of poor germination percentage in comparison to fastgrowing species (Pallewatta et al., 2003; Afrin, 2010). Nursery pre-sowing treatment is the primary and only step to recover these ecologically valuable threatened native trees by increasing their germination rate to compete with economically valuable exotics (Hossain and Pasha, 2001; Myers and Bazely, 2003). Appropriate pre-sowing treatment could only speed up germination rate and thus assure more germination of seeds sown. The present investigation was designed to find out the appropriate pre-sowing treatments for maximum germination percent of the species, particularly fourteen native threatened tree species of natural forests of Bangladesh. This paper will be a paradigm for future studies on pre-sowing treatment effects of other valuable tree species to restore on the earth from becoming extinct.

\section{Methodology}

\subsection{Study site, seed collection areas, times and pre-sowing treatments}

The experiment was carried out during 2012-13 in the Seed Research Laboratory, propagator house ${ }^{1}$ and the nursery of the Institute of Forestry and Environmental Sciences, Chittagong University (IFESCU), Bangladesh. The species along with their seed collection time, seed collection area and pre-sowing treatments are shown in Table 1.

\subsection{Germination percentage/ germination rate}

Germination was observed and recorded at every day after seeds sown and continued up to six months to find out the last germination of the seeds. Germination percentage was calculated by counting the number of seeds germinated out of 100 from beginning to end of the experiment (Dwivedi, 1993; Kumar, 1999).

Germination percentage $=\frac{\text { Number of seeds germinated }}{\text { Number of seeds sown }} \times 100$

\section{Results and Discussion}

The highest germination percentage $(100 \%)$ was found in P. semisagittatum when seeds were sown in commonly used polybags in flat position. Except $P$. serratum, highest germination was found only after providing pre-sowing treatments in the remaining 13 species. In B. elata, $96 \%$ germination was found when seeds sown in normal polybags without any pre-sowing treatment (control) and highest germination percentage (98\%) observed when sown in propagator house (Figure 1). C. resiniferum provided $20 \%$ germination rate when seeds sown without any pre-sowing treatment in normal polybags (control). But highest germination (33\%) was found in normal water treatment for 24 hours and $\mathrm{H}_{2} \mathrm{SO}_{4}$ treatment (10\%) for 3 minutes (Table 2). C. indica attained only $25 \%$ germination when seeds sown in polybags without any pre-sowing treatment (control), but highest germination (67\%) was observed when seeds were treated with sandpapers rubbing at the distal end and sown in polybags (Figure 1). D. polyantha showed $29 \%$ germination rate when seeds sown in normal polybags without any pre-sowing treatment (control), but germination increased up to $47 \%$ when sown in propagator house (Table 2).

\footnotetext{
${ }^{1}$ Propagator house: Greenhouse is a structure, primarily of glass, in which temperature and humidity can be controlled for the cultivation or protection of plants. Propagator house is one type of greenhouse with a bed consists of Sylhet sand with controlled temperature and humidity.
} 
Table 1: Seed collection areas, collection time and pre-sowing treatments provided to the species.

\begin{tabular}{|c|c|c|c|c|c|}
\hline Scientific name & $\begin{array}{l}\text { Local } \\
\text { name }\end{array}$ & $\begin{array}{l}\text { Hard/ soft } \\
\text { coated }\end{array}$ & $\begin{array}{l}\text { Seeds collected } \\
\text { from }\end{array}$ & $\begin{array}{l}\text { Fruit/seed } \\
\text { collection } \\
\text { (month) }\end{array}$ & Pre-sowing treatments \\
\hline Brownlowia elata & Moos & Soft & Ukhiya & August & 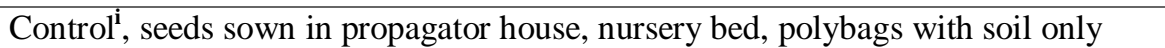 \\
\hline $\begin{array}{l}\text { Canarium } \\
\text { resiniferum }\end{array}$ & Dhup & Hard & $\begin{array}{l}\text { Adampur, } \\
\text { Moulavi Bazar }\end{array}$ & October & $\begin{array}{l}\text { Control, whole fruits sown in polybags, propagator house, seeds treated with } \\
\text { sandpaper, nicking, normal water ( } 24 \text { hours), hot water ( } 1 \text { minute), } \mathrm{H}_{2} \mathrm{SO}_{4} \text { ( } 3 \text { and } 5 \\
\text { minutes), } \mathrm{HCl} \text { ( } 3 \text { and } 5 \text { minutes), seeds sown in propagator house }\end{array}$ \\
\hline Castanopsis indica & $\begin{array}{l}\text { Shil } \\
\text { Batna }\end{array}$ & Hard & Dulhazara & August & $\begin{array}{l}\text { Control, seeds treated with sandpaper, nicking, normal water }(24,48,72 \text { hours), } \\
\left.\text { hot water ( } 1 \text { minute), } \mathrm{H}_{2} \mathrm{SO}_{4} \text { ( } 5 \text { minutes }\right), \mathrm{HCl}(5 \text { minutes }) \text {, seeds sown in } \\
\text { propagator house }\end{array}$ \\
\hline Dichopsis polyantha & Tali & Soft & Hazarikhil & March & Control, seeds sown in propagator house \\
\hline Firmiana colorata & Udal & Soft & $\begin{array}{l}\text { Ampu Para, } \\
\text { Bandarban }\end{array}$ & April & Control, seeds sown in propagator house \\
\hline $\begin{array}{l}\text { Lophopetalum } \\
\text { wightianum }\end{array}$ & Raktan & Soft & Lawachara & August & Control, seeds sown in propagator house and nursery bed \\
\hline Protium serratum & Gutgutia & Hard & Kaptai & September & $\begin{array}{l}\text { Control, seeds treated with sandpaper, nicking, normal water ( } 24 \text { hours), hot water } \\
\text { (1 minute), } \mathrm{H}_{2} \mathrm{SO}_{4} \text { ( } 1 \text { and } 3 \text { minutes), } \mathrm{HCl} \text { ( } 1 \text { and } 3 \text { minutes), fruits sown in } \\
\text { propagator house }\end{array}$ \\
\hline $\begin{array}{l}\text { Pterospermum } \\
\text { acerifolium }\end{array}$ & $\begin{array}{l}\text { Moochku } \\
\text { nda }\end{array}$ & Soft & Kaptai & April & Control, seeds sown in shade, flat position \\
\hline $\begin{array}{l}\text { Pterospermum } \\
\text { semisagittatum }\end{array}$ & $\begin{array}{l}\text { Lana } \\
\text { Asaar }\end{array}$ & Soft & $\begin{array}{l}\text { Chunati, } \\
\text { Satkania }\end{array}$ & April & Control, seeds sown in shade, flat position \\
\hline Pterygota alata & Narikeli & Soft & Rangpur & January & $\begin{array}{l}\text { Control, seeds sown with more than } 45^{\circ} \text { angles, under shade with straw, under } \\
\text { shade with chatai, in propagator house }\end{array}$ \\
\hline Quercus acuminata & $\begin{array}{l}\text { Kali } \\
\text { Batna }\end{array}$ & Hard & Dulhazara & August & $\begin{array}{l}\text { Control, seeds treated with sandpaper, nicking, normal water }(24,48,72 \text { hours), } \\
\left.\text { hot water ( } 1 \text { minute), } \mathrm{H}_{2} \mathrm{SO}_{4} \text { ( } 5 \text { minutes }\right), \mathrm{HCl} \text { ( } 5 \text { minutes), seeds sown in } \\
\text { propagator house }\end{array}$ \\
\hline Schleichera oleosa & Kusum & Soft & $\begin{array}{l}\text { Madhupur Sal } \\
\text { Forest, Tangail }\end{array}$ & September & $\begin{array}{l}\text { Control, seeds treated with sandpaper, nicking, normal water ( } 24 \text { hours), seeds } \\
\text { sown in propagator house }\end{array}$ \\
\hline Sterculia villosa & Udal & Soft & $\begin{array}{l}\text { Jibannagar, } \\
\text { Bandarban }\end{array}$ & April & Control, seeds sown in propagator house \\
\hline Vitex peduncularis & $\begin{array}{l}\text { Horina } \\
\text { Goda }\end{array}$ & Hard & Dulhazara & August & Control, seeds sown in propagator house, nursery bed \\
\hline
\end{tabular}


Table 2: Germination percentage of fourteen native threatened tree species after providing pre-sowing treatments in comparison to without any treatment (control).

\begin{tabular}{|c|c|c|c|c|c|c|}
\hline Scientific name & Local name & Family & $\begin{array}{c}\text { Germination } \\
(\%) \\
(* \text { Control })\end{array}$ & $\begin{array}{c}\text { Highest } \\
\text { germination } \\
(\%)\end{array}$ & $\begin{array}{l}\text { Pre-sowing } \\
\text { treatment(s) for } \\
\text { Highest }\end{array}$ & $\begin{array}{l}\text { Fruits/seeds } \\
\text { sown in }\end{array}$ \\
\hline B. elata & Moos & Apocynaceae & 96 & 98 & $\begin{array}{l}\text { Seeds sown in } \\
\text { Propagator house }\end{array}$ & Propagator house \\
\hline C. resiniferum & Dhup & Burseraceae & 20 & 33 & $\begin{array}{l}\text { Normal water } \\
(24 \text { hours), } 10 \% \\
\mathrm{H}_{2} \mathrm{SO}_{4}(3 \\
\text { minutes) }\end{array}$ & Polybag \\
\hline C. indica & Shil Batna & Fagaceae & 25 & 67 & $\begin{array}{l}\text { Seeds treated } \\
\text { with sandpaper }\end{array}$ & Polybag \\
\hline D. polyantha & Tali & Sapotaceae & 29 & 47 & $\begin{array}{l}\text { Seeds sown in } \\
\text { Propagator house }\end{array}$ & Propagator house \\
\hline F. colorata & Udal & Sterculiaceae & 83 & 95 & $\begin{array}{l}\text { Seeds sown in } \\
\text { Propagator house }\end{array}$ & Propagator house \\
\hline L.wightianum & Raktan & Celastraceae & 26 & 90 & $\begin{array}{l}\text { Seeds sown in } \\
\text { Propagator house }\end{array}$ & Propagator house \\
\hline$P$. serratum & Gutgutia & Burseraceae & 30 & 30 & Control & Polybag \\
\hline P. acerifolium & Moochkunda & Sterculiaceae & 63 & 77 & $\begin{array}{l}\text { Seeds sown flat } \\
\text { position }\end{array}$ & Polybag \\
\hline P. semisagittatum & Lana Asaar & Sterculiaceae & 87 & 100 & $\begin{array}{l}\text { Seeds sown flat } \\
\text { position }\end{array}$ & Polybag \\
\hline P. alata & Narikeli & Sterculiaceae & 74 & 86 & $\begin{array}{l}\text { Seeds sown in } \\
\text { Propagator house }\end{array}$ & Propagator house \\
\hline Q. acuminata & Kali Batna & Fagaceae & 77 & 88 & $\begin{array}{l}\text { Seeds treated } \\
\text { with sandpaper }\end{array}$ & Polybag \\
\hline S. oleosa & Kusum & Sapindaceae & 25 & 42 & $\begin{array}{l}\text { Seeds treated } \\
\text { with sandpaper, } \\
\text { normal water ( } 24 \\
\text { hours) }\end{array}$ & Polybag \\
\hline S. villosa & Udal & Sterculiaceae & 76 & 80 & $\begin{array}{l}\text { Seeds sown in } \\
\text { Propagator house }\end{array}$ & Propagator house \\
\hline V. peduncularis & Horina Goda & Verbenaceae & 38 & 46 & $\begin{array}{l}\text { Seeds sown in } \\
\text { Propagator house }\end{array}$ & Propagator house \\
\hline
\end{tabular}

*Control: Seeds sown in normal position in commonly used polybags (4"x6") only with a sowing media of soil and cowdung (3:1) in sun lights and without any pre-sowing treatment.

F. colorata seeds provide $83 \%$ germination in commonly used polybags without any pre-sowing treatment (control), but highest germination (95\%) was observed in propagator house (Table 2 ). In $L$. wightianum, only $26 \%$ germination was found in seeds without any pre-sowing treatment and sown in normal polybags (control) but it increased to $90 \%$ in propagator house. Highest germination of $P$. serratum was $30 \%$ and it was found in control (Figure 1).

Germination percentage of $P$. acerifolium and $P$. semisagittatum were $63 \%$ and $87 \%$ respectively in control while highest (77\% and $100 \%$ respectively) were found when seeds sown in flat position in polybags (Figure 1). In case of $P$. alata, $74 \%$ seeds were germinated when sown in polybags without any treatment, and highest germination (86\%) was found in propagator house. Q. acuminata exhibits $77 \%$ germination in control and highest rate $(88 \%)$ was observed when seeds rubbed with sandpaper at the distal end and sown in polybags (Table 2). 


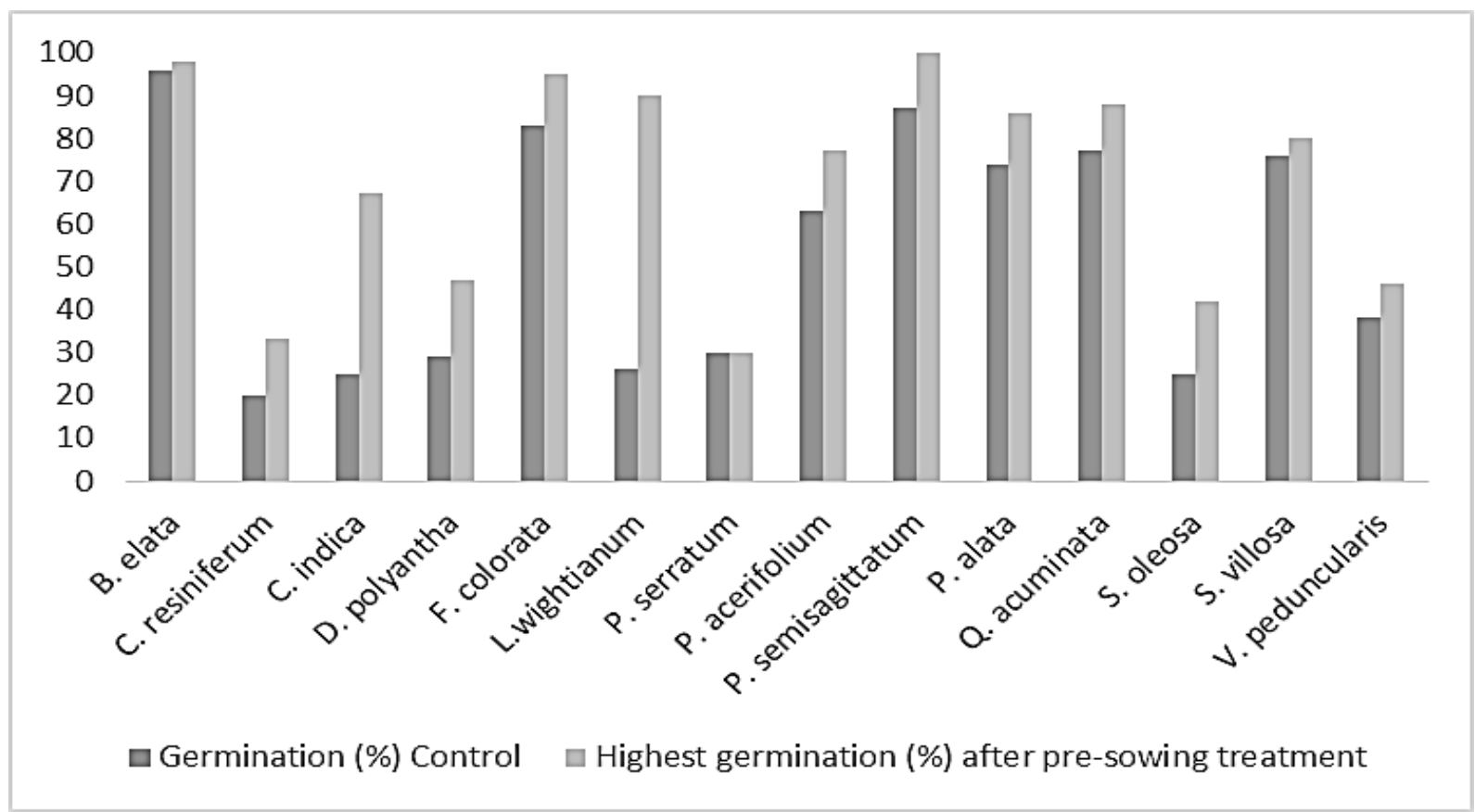

Figure 1. Germination percentage in control and highest germination percentage after pre-sowing treatment.

Highest germination percentage (42\%) of $S$. oleosa was found in seeds sown in polybags after treated with sandpaper rubbing at the distal end and normal water immersion treatment for 24 hours. However, without any pretreatment, it was only $25 \%$ (Figure 1). In S. villosa maximum germination $(80 \%)$ was found when seeds sown in propagator house, but in control it was $76 \%$ only. V. peduncularis seeds germinated $38 \%$ without any pre-sowing treatment (control) and highest germination rate was $46 \%$ found in seeds sown in propagator house (Table 2).

The findings of the study showed that, seeds sown in propagator house in sand bed offered highest germination percentage $98 \%, 47 \%, 95 \%, 90 \%, 86 \%, 80 \%$ and $46 \%$ respectively in soft-coated seeds of six species namely, B. elata (Figure 2), D. polyantha (Figure 5), F. colorata (Figure 6), L. wightianum (Figure 7), P. alata (Figure 11), S. villosa (Figure 14) and hard-coated seeds of V. peduncularis (Figure 15). Seeds with hard coat treated with normal water for 24 hours and $10 \%$ concentrated $\mathrm{H}_{2} \mathrm{SO}_{4}$ for 3 minutes provided highest germination percentage (33\%) in C. resiniferum (Figure 3) that supports the findings of Bebawi and Mohamed (1985); Hasnat et al. (2017); Laurent and Chamshama (1987) and Some et al. (1989). Hard coated seeds of $C$. indica (Figure 4) and Q. acuminata (Figure 12) showed maximum germination (67\% and $88 \%$ respectively) with sand paper treatment which supports the reports of Schmidt (2000). Soft-coated seeds of S. oleosa (Figure 13) also provided maximum germination (42\%) both in sandpaper treatment and normal water treatment for 24 hours (Hasnat et al., 2014). In $P$. acerifolium (Figure 9) and P. semisagittatum (Figure 10), maximum germination (77\% and $100 \%$ respectively) was observed when the seeds sown flat position in normal polybags. These results support that different pre-sowing treatments enhance germination rate of different species (Bewley and Black, 1982; Doran et al., 1983; Kumar, 1999; Napier, 1987; Palani et al., 1995; Schmidt, 2000). Only in $P$. serratum (Figure 8) the highest germination (30\%) was found in control. 


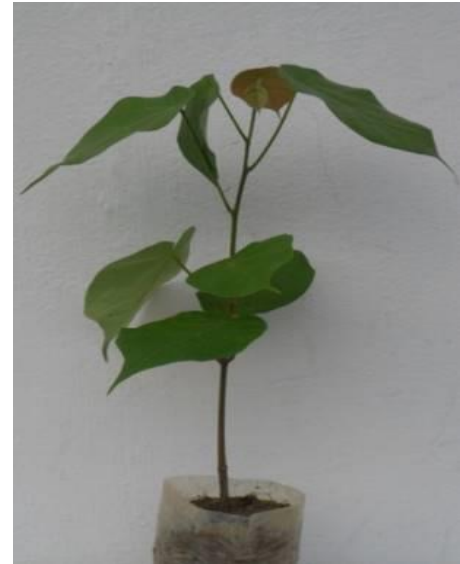

Figure 2. 60 days old seedling of Moos (Brownlowia elata) in poly-bag.

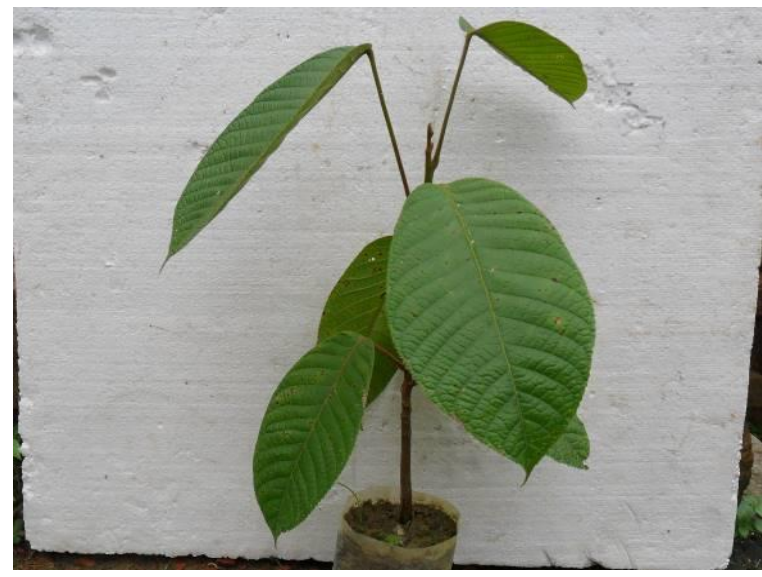

Figure 3. 90 days old seedling of Dhup (Canarium resiniferum).

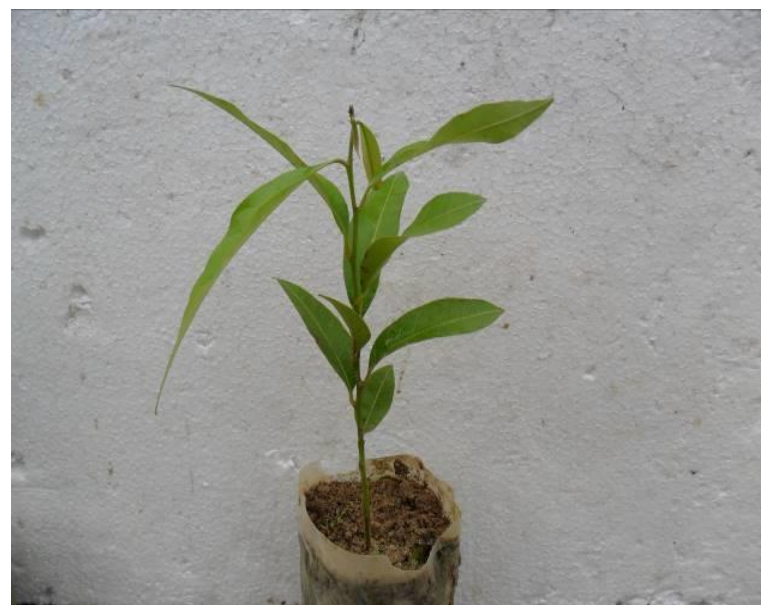

Figure 4. 90 days old seedling of Sil Batna (Castanopsis indica).

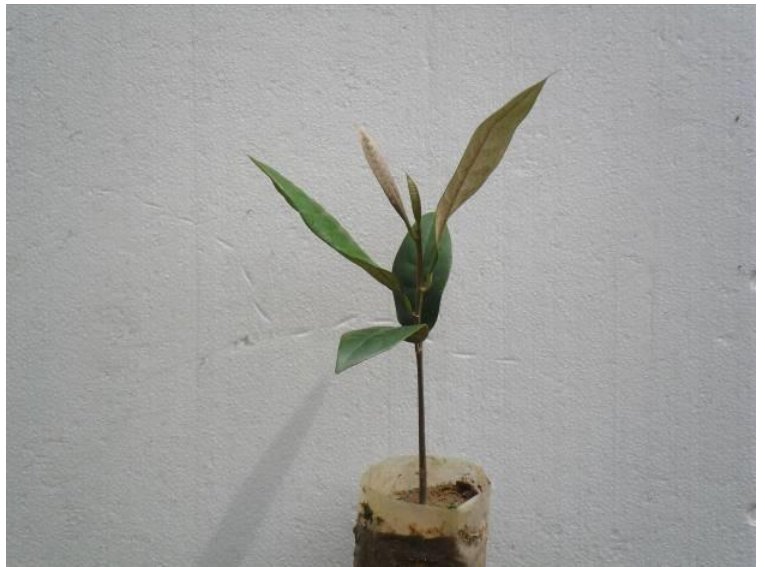

Figure 5. 90 days old seedling of Tali (Dichopsis polyantha).

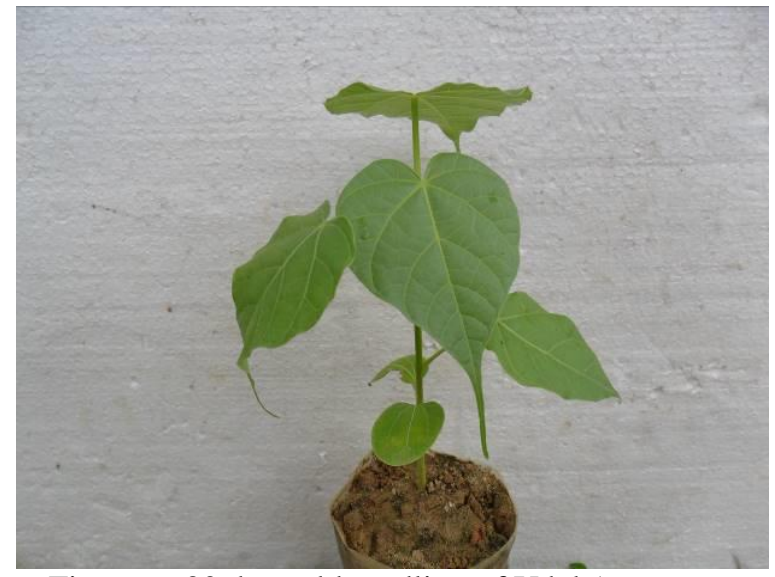

Figure 6. 30 days old seedling of Udal (Firmiana colorata).

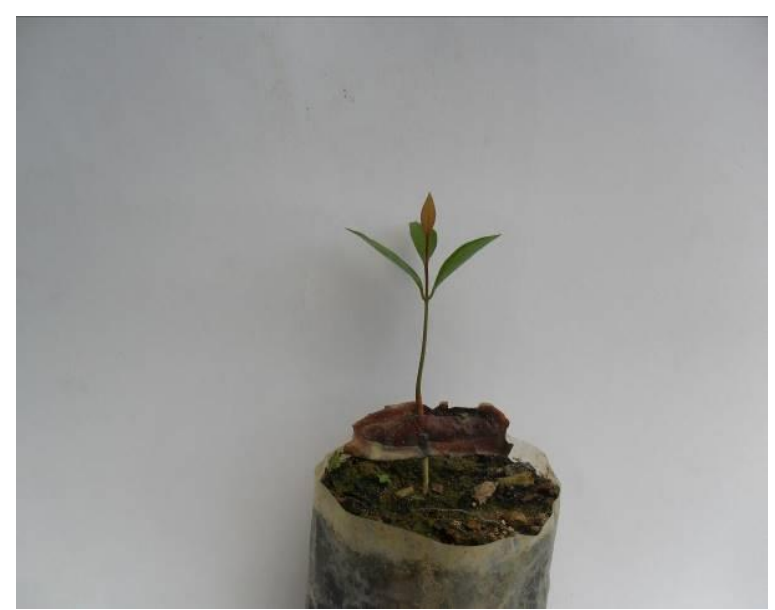

Figure 7. 45 days old seedling of Raktan (Lophopetalum wightianum). 


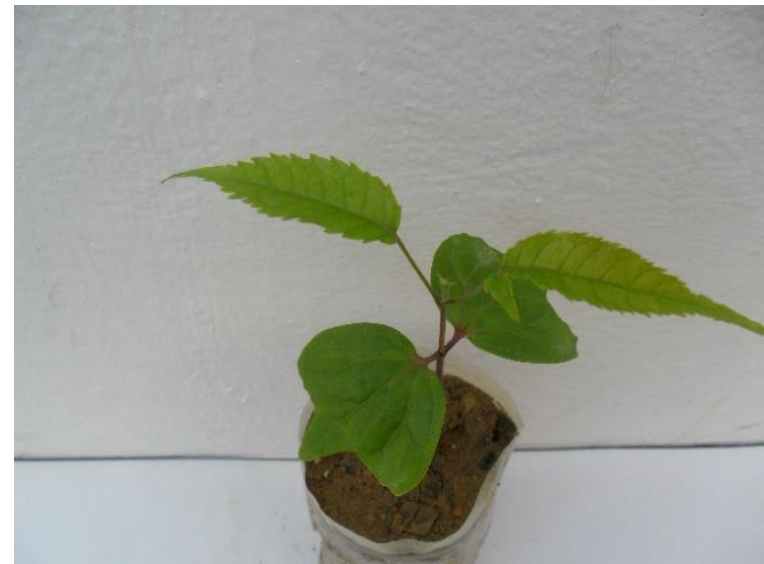

Figure 8. 15 days old seedling of Gutgutya (Protium serratum).

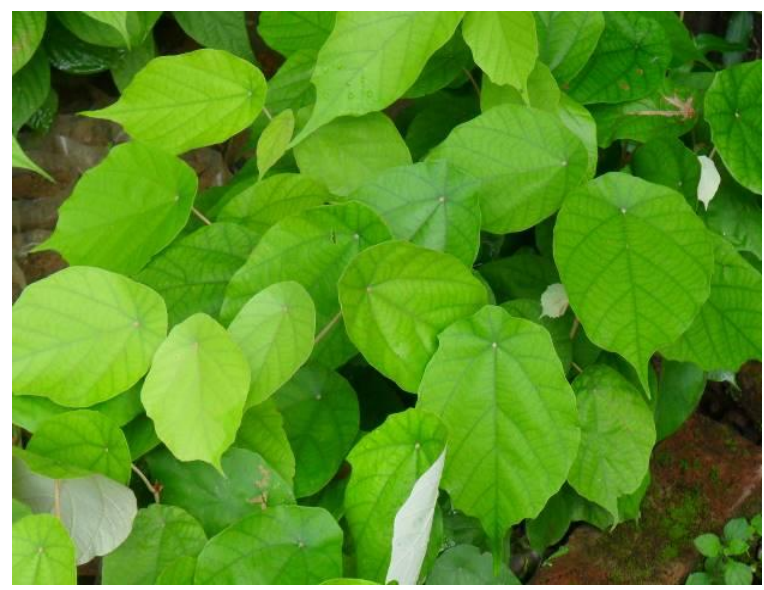

Figure 9. 90 days old seedlings of Mochkunda (Pterospermum acerifolium).

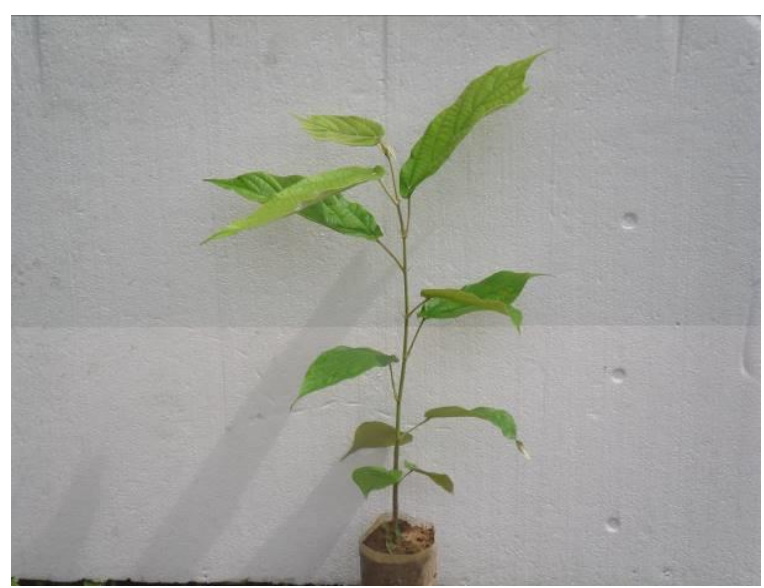

Figure 10. 90 days old seedling of Lana Assar (Pterospermum semisagittatum).

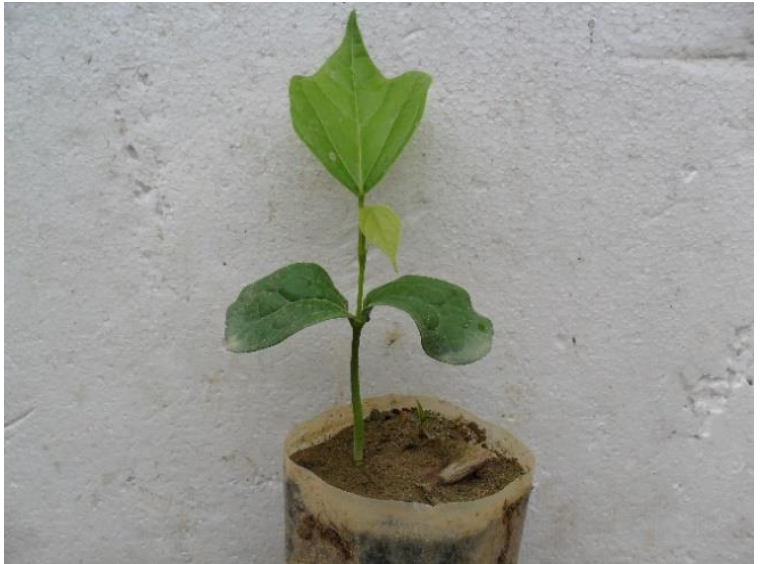

Figure 11. 30 days old seedling of Buddho Narikel (Pterygota alata).

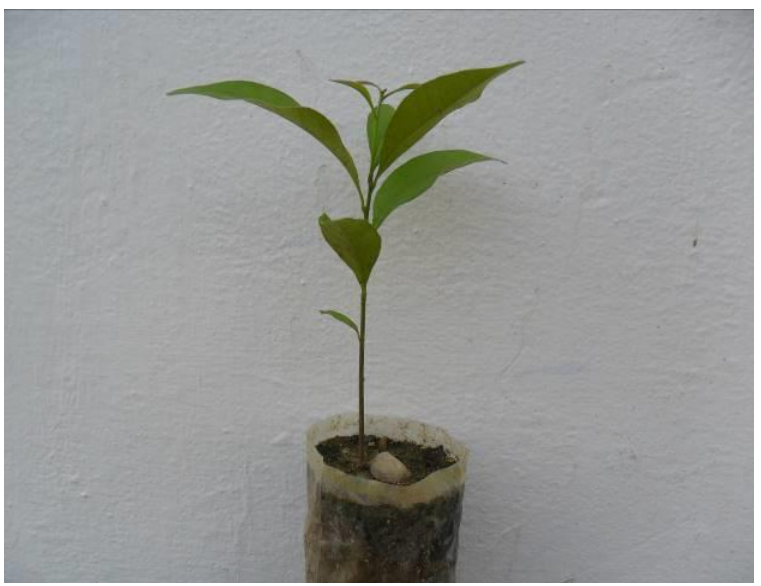

Figure 12. 40 days old seedling of Kali Batna (Quercus acumunata).

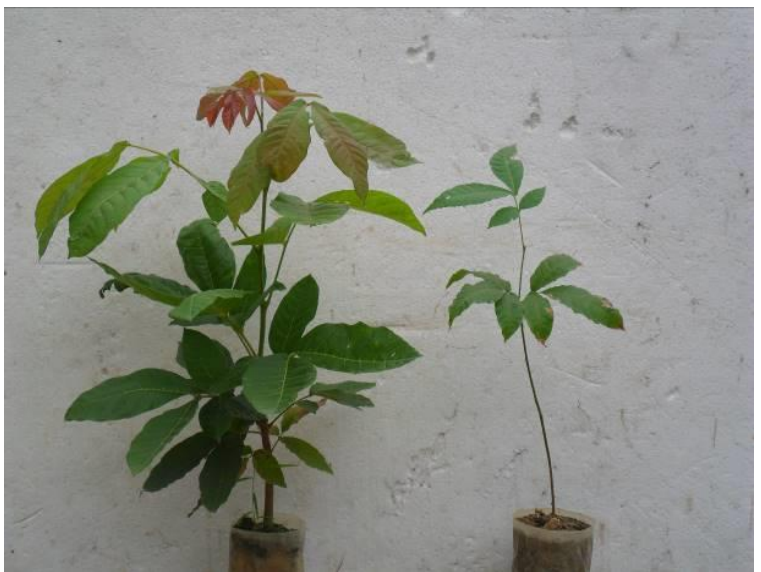

Figure 13. 150 days old seedlings of Kusum (Schleichera oleosa) [germinated in polybag (left) and transplanted from propagator house (right)]. 
Hasnat et al. /Journal of Tropical Forestry and Environment Vol. 9, No. 02 (2019) 36-45

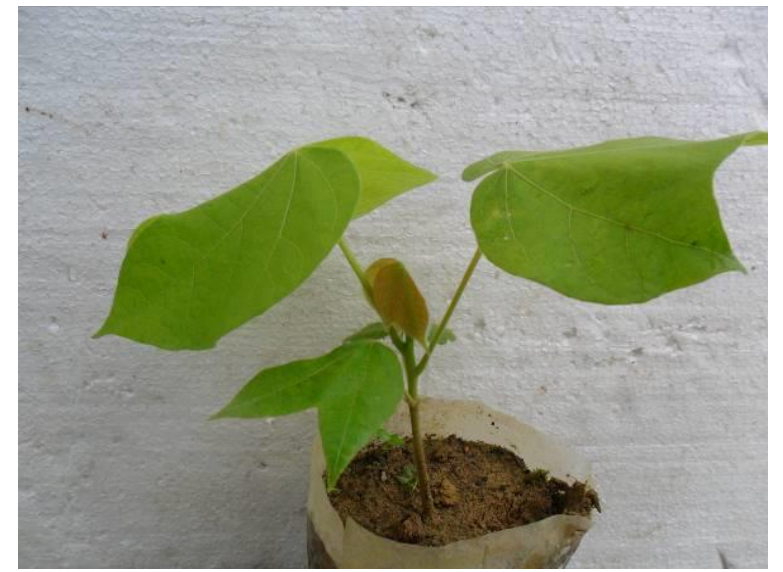

Figure 14. 30 days old seedling of Udal (Sterculia villosa).

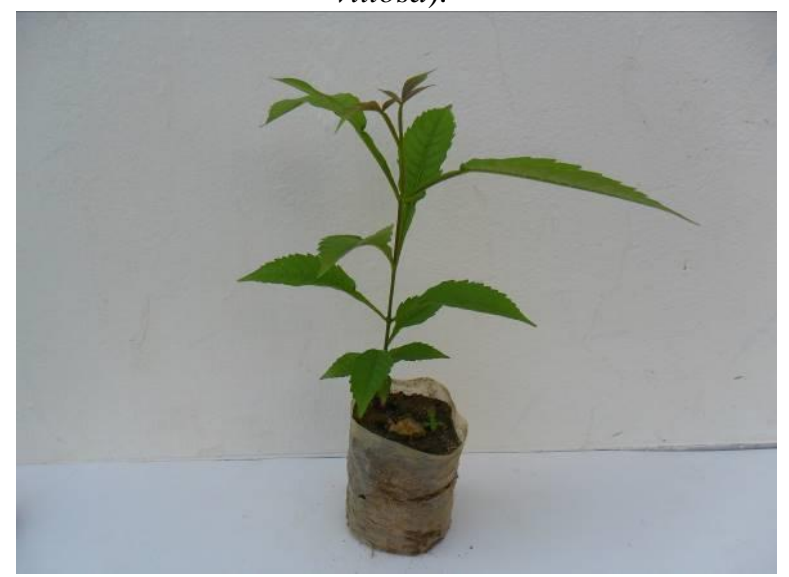

Figure 15. 50 days old seedling of Horina (Vitex peduncularis). 


\section{References}

Afrin, S., Sharmin, S. and Mowla, Q.A., 2010. The environmental impact of alien invasive plant species in Bangladesh. Proceedings of International Conference on Environmental Aspects of Bangladesh (ICEAB10), Japan, 62-64.

Bebawi, F.F. and Mohamed, S.M., 1985. The pretreatment of seeds of six Sudanese Acacias to improve their germination response. Seed Science and Technology, 13:111-119.

Bewley, J.D. and Black, M., 1982. Physiology and biochemistry of seeds in relation to germination, viability, dormancy and environmental control. Springer-Verlag, Berlin, 1-375.

Dolai, N., Karmakar, I., Kumar, R.B., Bala, A., Mazumder, U.K. and Haldar, P.K., 2012. Antitumor potential of Castanopsis indica (Roxb. ex Lindl.) A. DC. leaf extract against Ehrlich's ascites carcinoma cell. Indian Journal of Experimental Biology, 50:359-365.

Doran, J.C., Turnbull, J.W., Boland, D.J. and Gunn, B.V., 1983. Handbook on seeds of dry-zone Acacias. A guide for Collecting, Extracting, Cleaning, and Storing the Seed and for Treatment to Promote Germination of Dry-zone Acacias, Division of Forest Research, CSIRO, PO Box 4008, Canberra A C T 2600, Australia. 1-92.

Dwivedi, A.P., 1993. A Text Book of Silviculture. International Book Distributors. 9/3 RajpurRoad, Dehradun-248001, India.1-505.

Flores-Moreno, H., Thomson, F.J., Warton, D.I. and Moles, A.T., 2013. Are introduced species better dispersers than native species? A global comparative study of seed dispersal distance. PLoS ONE, 8, e68541.

Haque, A., Nandy, P. and Ahmed, F.U., 1997. Forest genetic resources conservation and utilization in Bangladesh. In Plant genetic resources- Bangladesh perspective (ed) Hossain, M.G., Arora, R.K. and Mathur, P.N. Proc. of a national workshop on plant genetic resources held on 26-29 August at BARC, Dhaka.104-132.

Hasnat, G.N.T., Hossain, M.K., Bhuiyan, M.K. and Alam, M.S., 2014. Effect of pre-sowing treatments on germination and initial growth of seedlings of Kusum (Schleichera oleosa). International Journal of Usufructs Management, 15:3-9.

Hasnat, G.N.T., Hossain, M.K., Alam, M.S. and Hossain, M.A., 2017. Effect of pre-sowing treatments on seed germination and seedling growth of Canarium resiniferum, a rare native tree of Bangladesh. Journal of Forest and Environmental Science, 33:226-232.

Hossain, M.K., 2001. A review of forest biodiversity conservation in Bangladesh. Journal of Forestry and Environment, 1:102-110.

Hossain, M.K., 2003. Exotic invasive plants in south-eastern hill forests of Bangladesh. 7th International Conference on the Ecology and Management of Alien Plant Invasions, November 3-11, 2003 at Wyndham Bonaventure Resort, Fort Lauderdale and Miami University, Florida, USA.

Hossain, M.K. and Pasha, M.K., 2001. Alien invasive plants in Bangladesh and their impacts on the ecosystem. In: Assessment and management of alien species that threaten ecosystems, habitats and species. Abstracts of keynote addresses and posters presented at the sixth meeting of the subsidiary body on scientific, technical and technological advice, held in Montreal, Canada, from 12-16 March. Montreal, Secretariat of the Convention on Biological Diversity (SCBD).73-75

Hossain, M.K., Rahman M.L., Hoque, A.T.M.R. and Alam, M.K., 2004. Comparative regeneration status in a natural forest and enrichment plantations of Chittagong (South) Forest Division, Bangladesh. Journal Forestry Research, 15:255-260.

Hossain, M.D., Hossain, M.A. and Hossain, M.K., 2012. Composition and diversity of tree species in Dud-pukuria natural forests of Chittagong (South) Forest Division, Bangladesh. Bangladesh Journal of Forest Science, 32:10-19. 
Irfanullah, H.M., 2011. Conserving threatened plants of Bangladesh: miles to go before we start? Bangladesh Journal of Plant Taxonomy, 18:1-91.

Islam, S.S., 2003. State of forest genetic resources conservation and management in Bangladesh. Forest Genetic Resources Working Papers. Working Paper FGR/68E. Forest Resources Development Service, Forest Resources Division, Forestry Department. Food and Agriculture Organization of the United Nations (FAO), Rome, Italy. 1-31

Khan, M.S., 1977. Flora of Bangladesh. Report 4. Commelinaceae. Bangladesh National Herbarium, Bangladesh Agriculture Research Council (BARC), Farmgate, Dhaka.

Khan, M.S., Rahman, M.M. and Ali, M.A. (ed) 2001. Red Data Book of Vascular Plants of Bangladesh. Bangladesh National Herbarium. Binimoy Printers, 37/2 Purana Paltan, Dhaka-1000.

Klink, C.A., 1996. Germination and seedling establishment of two native and one invading African grass species in the Brazilian Cerrado. Journal of Tropical Ecology, 12:139-147.

Kumar, V., 1999. Nursery and Plantation Practices in Forestry. Scientific Publishers, 5A, New Pali Road, PO Box 91, Jodhpur-342001.1-531.

Laurent, N., Chamshama, S. A. O., 1987. Studies on the germination of Erythrina abyssinica and Juniperus procera. The International Tree Crops Journal, 4:291-298.

Mangla, S., Sheley, R.L., James, J.J. and Radosevich, S.R., 2011. Intra and interspecific competition among invasive and native species during early stages of plant growth. Plant Ecology, 212:531542.

Myers, J.H., Bazely, D., 2003. Ecology and control of introduced plants. Published by the Press Syndicate of the University of Cambridge the Pitt Building, Trumpington Street, Cambridge, United Kingdom.1-313.

Napier, I., 1987. Pre-germination treatment of Cassia siamea and Leucaena leucocephala seeds. Banko Janakari, 1:5-6.

Palani, M., Dasrhagir, M.G. and Kumaran, K., 1995. Effect of pre-sowing chemical treatment on germination and seedling growth in Acacia nilotica. International Tree Crops Journal, 8:189192.

Pallewatta, N., Reaser, J.K. and Gutierrez A.T., 2003. Invasive alien species in South-southeast Asia: National Reports and Directory of Resources. Global Invasive Species Programme, Cape Town, South Africa. 1-111.

Schmidt, L., 2000. Guide to Handling Tropical and Subtropical Forest Seed. Danida Forest Seed Center, Krogerupvej 21, DK-3050 Humleback, Denmark. 1-510.

Some, L.M., Gamene, C.S. and Verwey, H., 1989. A study of the causes of poor germination of Anogeissus leiocarpus seeds. In: Tropical tree seed research (ed) Turnbull, J.W. Proceedings of an international workshop held at the Forestry Training Centre, Gympie, Qld, Australia, 21-24 August, ACIAR, 28:37-40.

Uddin, S.M.M. and Misbahuzzaman, K., 2007. Tree species diversity in Dulhazara Safari Park of Bangladesh. Malaysia Applied Biology, 36:33-40.

Uddin, M.B., Steinbauer, M.J., Jentsch, A., Mukul, S.A. and Beierkuhnlein, C., 2013. Do environmental attributes, disturbances and protection regimes determine the distribution of exotic plant species in Bangladesh forest ecosystem? Forest Ecology and Management, 303:72-80.

Wainwright, C.E.and Cleland, E.E., 2013. Exotic species display greater germination plasticity and higher germination rates than native species across multiple cues. Biological Invasion 15:22532264.

IUCN, 1998. Lophopetalum wightianum. World Conservation Monitoring Centre. The IUCN Red List of Threatened Species. 
